\title{
KEPEMIMPINAN KEPALA SEKOLAH ( Studi Kasus di SMP Kolese Kanisius Jakarta )
}

\section{Yohanes Andhi Kurniawan*}

\begin{abstract}
The objective of this research was to understand and to get picture of organizational communication, decision making and reward that used by School Principal at Canisius College Junior High School Jakarta.

The data were collected through participant observation using interview, observation, document study and recording. The data analysis and interpretation indicates that (1) the interpersonal communication system is a main communication system, social networking and electronic communication become the main support in developing the communication. The communication that occurs such as oral, written and nonverbal communication which is applied in Downward communication nor Upward communication, (2) Decision was taken as a programmed and nonprogrammed decisions. The programmed decisions is the main task of a school leader and the nonprogrammed decisions is the strategic policy that taken to achieving the goal of the school which refers to the schools vision and mission, (3) The awarding highly prioritized both the intrinsic reward and extrinsic reward so that the teachers, staff and students feel very appreciated. It will always provide the best work for the school.
\end{abstract}

Keywords : Principal Leadership, Canisius College and Qualitative

\section{PENDAHULUAN}

Perkembangan lembaga pendidikan formal yakni sekolah baik negeri, swasta maupun sekolah bertaraf internasional sangatlah pesat. Pemerintah terus mendorong perkembangan kualitas sekolah dengan berbagai cara termasuk menaikkan anggaran negara untuk bidang pendidikan. Persaingan sekolah baik negeri maupun swasta tidak terhindarkan. Sekolah negeri mendapatkan bantuan pemerintah dalam pembiayan operasional sekolah termasuk pengadaan sarana dan prasarana. Sekolah swasta dengan kemampuan yayasan masing-masing terus berusaha untuk meningkatkan kualitas pendidikan sekolahnya.

SMP Kanisius Jakarta merupakan salah satu sekolah yang memiliki sejarah latar belakang pendiri dan perkembangannya kurang lebih 4 abad. SMP Kolese Kanisius berdiri sejak 1952 merupakan sekolah Homogen yakni hanya menerima siswa putra saja hingga saat ini. Dalam kurun waktu 64 tahun ini SMP Kanisius mampu bertahan dan menjaga mutu pendidikannya ditengah semakin banyaknya sekolah swasta dan sekolah bertaraf internasional di Jakarta. SMP Kanisius dipimpin oleh seorang rohaniwan, yaitu seorang Pastor yang melalui jenjang pendidikan Theologi hingga di Tahbiskan dan memiliki wewenang untuk memimpin Misa atau Ibadah di Gereja Katholik. Pemimpin Gereja Katholik memiliki kekhasan yaitu Kaul atau janji untuk tidak menikah seumur hidup. 
Kehidupan tanpa keluarga ini merupakan kelebihan yang dimiliki seorang pemimpin sekolah sehingga waktu, tenaga serta pikiran bisa tercurah secara maksimal untuk memimpin sebuah sekolah yang dipercayakan padanya.

Perkembangan kualitas pendidikan sekolah menuntut kemampuan manajerial yang berkualitas pula. Kemampuan berkomunikasi dalam organisasi, pengambilan keputusan dan pemberian perhargaan yang tepat akan mampu meningkatkan kemajuan sekolah ditengah persaingan dunia pendidikan yang semakin maju dan modern.

Penelitian kualitatif ini menggunakan penelitian studi kasus dengan sumber data adalah kepala sekolah, guru, karyawan serta siswa SMP Kanisius yang merupakan bagian utuh dari sebuah proses perkembangan kemajuan sekolah ini. Teknik wawancara, observasi partisipan dan analisa dokumen yang dilaksanakan digunakan sebagai prosedur pengumpulan datanya. Perpannjangan waktu penelitian dan triangulasi teknik pengumpulan data dan sumber data digunakan untuk menunjukkan keabsahan data.

\section{Kepemimpinan}

Schermerhorn (2011:306) mendefinisikan kepemimpinan, yaitu "leadership is the process of influencing others and process of facilitating individual and collective effort to accomplish shared objectives". Kepemimpinan ialah proses mempengaruhi orang lain dan proses mempermudah usaha seseorang atau kelompok untuk menyelesaikan tujuannya. Menurut Ivancevich (2007:202) dalam model Vroom-Jago, kepemimpinan ini memperhatikan keefektifan keputusan, gaya keputusan dan prosedur diagnotik. Kriteria kefektifan keputusan melibatkan kualitas keputusan yang berkaitan dengan sejauh mana keputusan mempengaruhi kinerja sedangkan komitmen bawahan berkaitan dengan seberapa penting bawahan berkomitmen atau menerima keputusan agar keputusan tersebut dapat diimplementasikan. Model kepemimpinan jalur tujuan (path-goal leadership model) menurut Ivancevich (2007:205) menjelaskan tentang usaha memprediksi keefektifan kepemimpinan dalam berbagai situasi. Dalam model ini pemimpin menjadi efektif karena efek positif yang mereka berikan terhadap motivasi para pengikut, kenerja dan kepuasan. Peran pemimpin yang terpenting adalah memberikan kepada bawahan tentang perilaku yang paling mungkin menghasilkan pencapaian tujuan. Gaya kepemimpinan yang lain menurut Ivancevich (2014:448) adalah model kepemimpinan situasional Hersey-Blanchard mengembangkan empat gaya kepemimpinan yakni telling, selling, participating, and delegating. Bentuk kepemimpinan situasional yang lain adalah kepemimpinan karismatik, kepemimpinan transaksional dan kepemimpinan transformasional. Kepemimpinan karismatik adalah kepemimpinan yang memiliki karisma dengan pemahaman bahwa karisma merupakan kombinasi dari pesona dan daya tarik pribadi yang berkontribusi terhadap kemampuan luar biasa untuk orang lain mendukung visi dan mempromosikannya dengan semangat. Kepemimpinan transformasional adalah kepemimpinan dimana pemimpin memotivasi bawahan terhadap tujuan, 
bukan untuk kepentingan pribadi jangka pendek dan untuk mencapai prestasi dan aktualisasi diri bukan demi perasaan aman, mampu mengekspresikan visi yang jelas dan menginspirasi orang untuk menjulang mencapai visi tersebut.

\section{Kepala Sekolah}

Standar kinerja kepala sekolah merefleksikan kompleksitas tugas yang terus meningkat, dengan sekian banyak seri panduan dan standar kinerja kepala sekolah yang ditetapkan oleh lembaga pemerintahan pusat dan lokal.

Menurut James H. Stronge (2013:121) berdasarkan hasil-hasil riset yang dilakukan oleh Council Of Chief State School Officer menetapkan enam standar yang mengidentifikasikan administrator sekolah adalah pemimpin pendidikan ( kepala sekolah ) yang mendorong kesuksesan seluruh siswa dengan cara ; Memfasilitasi adanya visi bersama, Mendorong kultur sekolah dan program-program pengajaran yang berfokus pada perkembangan siswa-siswi dan staf sekolah, Menjalankan manajemen dan operasional setiap hari, Membangun hubungan dengan keluarga siswa dan komunitas yang lebih luas, Bertindak secara adil dan beretika, Merespon dan memengaruhi politik, sosial, ekonomi, hukum dan kultur dalam konteks yang lebih luas.

American Assosiation of Shool Administrators (AASA) menurut James H. Stronge (2013:125) mengeluarkan satu seri standar sebagai panduan bagi para pemimpin pendidikan, dimana standar ini mewajibkan bahwa pelaksanaan tugas - tugas profesional harus mengikuti kode etika perilaku.

\section{Kepemimpinan Kepala Sekolah}

\section{a. Komunikasi dalam organisasi (Organizational Communication)}

Schermerhorn et.all (2011:256) mendefinisikan komunikasi, yaitu "communication is the process of sending and receiving symbols with attached meaning". Komunikasi adalah proses dari mengirim dan menerima simbol dengan pengertian yang melekat. John. M. Ivancevich (2014:373-374) menyebutkan tentang proses komunikasi yang terjadi dalam sebuah organisasi. Disebutkan bahwa proses komunikasi yang terjadi dalam organisasi dibedakan menjadi 4 arah, yakni : Downward Communication, Upward Communication, Horizontal Communication, Diagonal Communication.

Teknologi yang semakin maju mewujudkan media komunikasi baru. Perkembangan tersebut memunculkan media internet, intranet dan ekstranet. Bentuk media komunikasi yang lain yang merupakan perkembangan dari teknologi yang semakin maju adalah surat elektronik (email), pesan instan (instant messaging /IM), pesan suara (voice mail), konferensi video dan telekonferensi, smartphone, dan pertemuan elektronik (e-meeting).

\section{b. Pengambilan keputusan (Decision Making)}

Schermerhorn et.al (2011:206) mendefinisikan pengambilan keputusan, yaitu "decision making is the process of choosing a course of action to deal with a 
problem or opportunity". Pengambilan keputusan adalah sebuah proses dari memilih rangkaian tindakan berhubungan dengan masalah atau kesempatan. John M. Ivancevich et.all (2014:401) mendefinisikan pengambilan keputusan, yaitu "decision making is defined as the process of choosing a particular action that deals with a problem or opportunity". Pengambilan keputusan didefinisikan sebagai sebuah proses pemilihan tindakan pribadi yang berhubungan dengan masalah atau kesempatan.

Pengambilan keputusan dapat menggunakan model yang berbeda yakni model pengambilan keputusan terprogram dan tak terprogram (programmed and nonprogrammed decision). Kualitas seorang pemimpin salah satunya adalah kemampuan mengambil keputusan yang paling tepat dan bijaksana berdasarkan pertimbangan yang ada untuk mengatasi suatu masalah.

Perilaku seorang pemimpin sangat berpengaruh terhadap sebuah pengambilan keputusan. Hal ini dipengaruhi oleh nilai, kecenderungan terhadap resiko, potensi terhadap disonansi serta peningkatan komitmen. Nilai merupakan pedoman dan keyakinan yang dipakai seseorang saat berhadapan dengan situasi penetapan pilihan.

\section{c. Pemberian penghargaan ( Reward)}

John M. Ivancevich et.all (2014:179) menyatakan bahwa tujuan utama dari pemberian penghargaan adalah : (1) memikat orang yang ahli untuk bergabung dengan organisasi, (2) menjaga karyawan untuk datang bekerja, dan (3) memotivasi karyawan meraih kinerja dengan level yang tinggi. Pemberian penghargaan kepada karyawan akan menumbuhkan rasa memiliki serta rasa tanggung jawab yang besar untuk terus meningkatkan kinerjanya sehingga perusahaan atau suatu organisasi tersebut akan semakin maju dan berkembang.

Intrinsic reward adalah completion, achievement, autonomy dan personal growth. Pemahaman dari completion adalah kemampuan untuk memulai dan menyelesaikan proyek atau pekerjaan bagi seseorang. Achievement atau prestasi adalah penghargaan terhadap keberhasilan diri yang diperoleh ketika seseorang meraih pencapaian yang menantang. Autonomy berarti bahwa setiap orang yang bekerja memperoleh hak dan hak istimewa untuk membuat keputusan dan menjalankannya tanpa pengawasan yang ketat. Pemahaman dari personal growth adalah perkembangan diri seseorang dimana dengan memperluas kemampuannya akan mampu memaksimalkan atau setidaknya memuaskan potensi ketrampilannya.

Extrinsic reward adalah financial rewards, interpersonal rewards dan promotion. Financial rewards yang pertama disebut sebagai salary dan wages atau penghargaan yang berujud uang antara lain yaitu gaji dan upah. Penghargaan finansial yang kedua adalah employee benefit atau tunjangan karyawan yang terdiri dari tunjangan pensiun, kesehatan atau rumah sakit, liburan. Interpersonal rewards atau penghargaan perseorangan dapat dieroleh dari seorang pimpinan atau manajer yang memiliki kewenangan untuk memberikan penghargaan 
perseorangan ini sebagai kedudukan atau pengakuan. Hal yang ketiga yang merupakan penghargaan ekstrinsik adalah promotion, dimana tidak setiap orang berkesempatan untuk memperolehya. Seorang pimpinan memutuskan untuk memberi penghargaan berupa promosi berusaha untuk mencocokkan antara hak seseorang dengan pekerjaannya.

\section{METODE}

Penelitian ini dilaksanakan di SMP Kolese Kanisius Jakarta. Pelaksanaan penelitian dimulai dari bulan Februari 2012 - September 2012 dilanjutkan bulan februari 2015 - Februari 2015. Pelaksanaan kegiatan ini dibagi dalam beberapa tahapan. Tahap pertama, februari 2012 - april 2012 peneliti melakukan studi awal untuk mencari keunikan yang ada di SMP Kolese Kanisius Jakarta yang digunakan unutk menentukan fokus dan sub fokus penelitian. Tahap kedua, membuat desain penelitian berupa pedoman wawancara dan pedoman observasi untuk penggalian data. Tahap ketiga, mereduksi data untuk koding dalam pengelompokkan hasil observasi dan wawancara. Tahap keempat, menganalisa dan validasi data. Tahap kelima, membagi hasil temuan yang digunakan untuk rekomendasi. Pemeriksaan keabsahan data dalam penelitian ini dilakukan dengan kriteria : (1) Kredibilitas ( Perpanjangan pengamatan, ketekunan peneliti, Triangulasi), (2) Tranferabilitas, (3) Dependabilitas dan (4) Konfirmabilitas.

\section{HASIL PENELITIAN DAN PEMBAHASAN}

Komunikasi dalam organisasi (Organizational Communication) di SMP Kolese Kanisius Jakarta.

Stephen P. Robin (2013:370) dalam bukunya menyatakan bahwa jalinan komunikasi memiliki 4 fungsi yakni ; kontrol, motivasi, ekspresi dan informasi. Komunikasi yang diterapkan di SMP Kanisius dimulai sejak wawancara penerimaan siswa baru. Penerapan sistem interpersonal communication merupakan langkah terbaik untuk mengawali proses pendidikan disekolah ini. John W. Newstrom menyampaikan dalam bukunya tentang bentuk lain dalam berkomunikasi. Social networking and electronic communication merupakan bentuk komunikasi yang semakin populer. Maka sekolah Kanisius komunikasi selanjutnya adalah setelah siswa lulus dari SMP Kanisius maka komunikasi sebagai alumni masih terus berlanjut. Stephen P. Robin (2013:374-375) menyatakan bahwa dalam interpersonal communication terdapat tiga jenis komunikasi yang dapat terjalin yakni oral communication, written communication and nonverbal communication. Dengan keterbatasan waktu yang dimiliki kepala sekolah serta kesempatan untuk bertatap muka dengan siswa dan orang tua maka bentuk komunikasi yang tertulis merupakan media yang dipilih sebagai alternatif. Media komunikasi berupa buku panduan akademik merupakan media yang sangat efektif bagi siswa maupun orang tua dengan pihak sekolah. Berdasarkan salah satu wewenang kepala sekolah yang tertuang dalam buku panduan akademik bahwa sekolah menjalin relasi 
kemitraan kerja dengan pihak luar baik dari dalam maupun dari luar negeri maka Kepala sekolah SMP Kanisius yang saat ini menjabat sebagai ketua Majelis Pendidikan Katolik tingkat SMP , yakni sebuah lembaga yang menaungi sekolah yayasan katolik di keuskupan Agung Jakarta, melakukan koordinasi serta komunikasi dengan seluruh pimpinan sekolah katolik tingkat SMP se DKI Jakarta. John. M. Ivancevich (2014:373) menyatakan bahwa "downward communication is a communication that flow from individuals in higher levels of the organization's hierarchy to those in lower levels". Komunikasi Kepala sekolah dengan guru memiliki agenda rutin yaitu rapat setiap bulannya. Hal yang unik disekolah ini adalah adanya kesempatan bagi seluruh guru untuk melakukan refleksi atas apa yang telah dilaksanakan bersama dalam melaksakan program kerja selama ini maupun memberikan usulan atau masukan bagi kepala sekolah untuk lebih memajukan sekolah. Dalam komunikasi diluar forum rapat maka kepala sekolah selalu memberikan kesempatan seluas-luasnya jika ada guru yang memerlukan konsultasi maupun arahan dalam menjalankan tugas mengajarnya maupun jika akan menyampaikan hal lainnya. Di setiap kesempatan waktu yang ada baik pada pagi sebelum jam pelajaran mulai maupun saat jam istirahat Kepala sekolah seringkali menyempatkan diri ke ruang guru dalam rangka menyapa guru ataupun hanya berbicara ringan dengan para guru. Pada kesempatan lain Kepala Sekolah menegur karyawan atau menyampaikan himbauan kepada karyawan jika beliau melihat hal yang kurang berkenan. Kegiatan rutin yang dilakukan setiap senin pagi adalah Briefing atau apel pagi. Pada kegiatan ini, Kepala Sekolah memiliki kesempatan langsung berkomunikasi dengan siswa secara langsung. Hal utama dalam kegiatan ini adalah kesempatan kepala sekolah untuk menyampaikan tentang visi misi sekolah yang dikemas dengan cara komunikasi secara interaktif yang menuntut siswa untuk berani menyampaikan pendapat secara langsung dihadapan guru serta seluruh teman satu sekolah. Pada kesempatan ini kepala Sekolah memberikan penghargaan atau apresiasi bagi mereka yang berani mengemukakan pendapat atau menjawab pertanyaan yang dilontarkan olehnya. Predikat akreditasi " $\mathrm{A}$ " setiap tahunnya hingga saat ini menunjukkan kualitas pendidikan yang dilaksanakan oleh sekolah ini masih sangat baik menurut penilaian dinas pendidikan. Segala macam bentuk komunikasi antara sekolah dengan dinas pendidikan didelegasikan kepada wakil kepala sekolah bidang kurikulum. SMP dan SMA Kanisius memiliki satu lokasi yang sama dengan Yayasan Budi Mulia yang manaunginya. Kepala sekolah SMA dan SMP serta Kepala yayasan yang disebut sebagai rektor merupakan rohaniwan Jesuit yang yang tinggal bersama dalam rumah dinas yang masih satu lingkungan dengan sekolah. Hal ini sangat mendukung dalam segala yang berhubungan dalam kegiatan komunikasi baik yang formal maupun non formal. Dengan kata lain bahwa hal yang berkaitan dengan masalah sekolah bisa dibicarakan dalam forum rapat resmi maupun sampai pada saat di meja makan.

Seiring dengan perkembangan teknologi maka media internet sangat dimanfaatkan sebagai media komunikasi yang sangat efektif. Pihak sekolah bisa 
dengan luas menyampaikan seluruh informasi tentang sekolah dapat diakses oleh siapapaun termasuk siswa sendiri, orang tua siswa, alumni maupun masyarakat pada umumnya yang ingin mengetahui ataupun mengenal sekolah kanisius.

Pengambilan keputusan (Decision Making) di SMP Kolese Kanisius Jakarta.

John M. Ivancevich et.all (2014:401) mendefinisikan pengambilan keputusan, yaitu "decision making is defined as the process of choosing a particular action that deals with a problem or opportunity". Pengambilan keputusan didefinisikan sebagai sebuah proses pemilihan tindakan pribadi yang berhubungan dengan masalah atau kesempatan. Pengambilan keputusan seorang pemimpin terbagi dalam 2 tipe yakni programmed decisions dan nonprogrammed decisions. Programmed decisions is a situations in which spesific procedures have been developed for repetitive and routine problems. Berdasarkan tanggung jawab serta wewenang yang dimiliki, kepala sekolah merupakan pemegang hak dalam pengambilan keputusan. Wewenang kepala sekolah mengenai pemilihan staf kerja dan mengusulkan ke pihak yayasan Budi Siswa untuk pengesahan atau pengangkatan, mengadakan evaluasi staf untuk kenaikan jenjang kepangkatan/golongan kerja, memanggil dan memberikan teguran baik secara lisan maupun tertulis (surat peringatan) terhadap pegawai edukatif yang melanggar disiplin dan kode etik profesi sebagaimana telah digariskan oleh yayasan Budi Siswa merupakan pengambilan keputusan tipe programmed decisions.

Nonprogrammed decisions merupakan pengambilan keputusan yang diambil untuk mengatasi masalah manajemen yang unik dan komplek. Kebijakan yang diambil oleh kepala sekolah adalah perubahan jumlah paralel kelas. kebijakan selanjutnya adanya penerapan sistem moving class. Sistem moving class merupakan keputusan yang membutuhkan persiapan dan pemikiran yang mendalam karena jika kurang persiapan maka situasi belajar mengajar akan jadi berantakan dan mengacaukan situasi proses belajar mengajar. Kebijakan berikutnya adalah adanya pemberian penghargaan untuk siswa yang dibuat lebih banyak mengapresiasi seluruh kegiatan siswa serta prestasi yang diraihnya baik dibidang akademis maupun non akademis. Kegiatan research paper atau karya tulis ilmiah merupakan program sekolah yang diterapkan oleh Kepala Sekolah. Hasil dari karya tulis ilmiah ini menjadi salah satu syarat siswa kelas IX untuk bisa mengikuti ujian sekolah dan ujian nasional. Berdasarkan observasi dan wawancara yang dilaksanakan peneliti, kepala sekolah sangat menunjukkan adanya sifat visioner yang sangat melekat pada diri seorang kepala sekolah rohaniawan Jesuit. Hal sangat bisa di pahami karena visi dan misi sekolah merupakan visi dan misi sekolah yang disusun berdasarkan visi pelayanan rohaniwan Jesuit.

\section{Pemberian penghargaan ( Reward) di SMP Kolese Kanisius Jakarta.}

John M. Ivancevich et.all (2014:179) menyatakan bahwa tujuan utama dari pemberian penghargaan adalah : (1) memikat orang yang ahli untuk bergabung dengan organisasi, (2) menjaga karyawan untuk datang bekerja, dan (3) memotivasi 
karyawan meraih kinerja dengan level yang tinggi. Pemberian penghargaan kepada karyawan akan menumbuhkan rasa memiliki serta rasa tanggung jawab yang besar untuk terus meningkatkan kinerjanya sehingga perusahaan atau suatu organisasi tersebut akan semakin maju dan berkembang. Proses sebuah pemberian penghargaan berawal dari motivasi untuk mengerahkan segala daya untuk menciptakan unjuk kerja individu yang dipengaruhi oleh kemampuan, ketrampilan dan pengalaman. Kemudian diadakan evaluasi unjuk kerja yang akan mewujudkan kepuasan yang dipengaruhi oleh intrinsic reward dan extrinsic reward.

Intrinsic reward adalah completion, achievement, autonomy dan personal growth. Berdasarkan data yang diperoleh sejak tahun ajaran 2012/2013 sampai dengan 2014/2015 maka pemberian penghargaan kepada siswa adalah penghargaan bidang Akademis ( Science Award, Linguistic Award), Penghargaan didang non Akademis / Humaniora ( Sport Award, Art Award, Leadership Award,

Canisian Award)

Extrinsic reward adalah financial rewards, interpersonal rewards dan promotion. Seorang pimpinan memutuskan untuk memberi penghargaan berupa promosi berusaha untuk mencocokkan antara hak seseorang dengan pekerjaannya. Berdasarkan hasil wawancara dengan guru dan karyawan maka banyak hal yang telah dirasakan sebagai bentuk penghargaan yang diterima dari sekolah. Hal yang dirasakan sebagai penghargaan yang utama adalah adanya gaji yang diterima dengan adanya tambahan tunjangan transportasi, tunjangan makan, intensif kehadiran, gaji ke 13, penghargaan tiap 5 tahunan serta asuransi kesehatan.

\section{PENUTUP}

Kesimpulan. (1) Penerapan sistem interpersonal communication merupakan langkah terbaik untuk mengawali proses pendidikan disekolah ini. Dengan memperhatikan information richness and communications channels tersebut maka bentuk komunikasi awal setelah siswa diterima adalah pertemuan diawal tahun ajaran baru antara pihak sekolah dengan orang tua siswa.. Komunikasi ini bisa dilakukan antara pihak orang tua dengan wali kelas, guru bidang studi maupun dengan wakil kepala sekolah bidang kesiswaan. Social networking and electronic communication merupakan bentuk komunikasi yang dimanfaatkan untuk menjalin komunikasi dengan para alumni dan masyarakat umum. Bentuk komukasi berikutnya adalah written communication, media komunikasi berupa buku panduan akademik merupakan media yang sangat efektif bagi siswa maupun orang tua dengan pihak sekolah. Downward communication dan Upward communication yang terjalin di SMP Kanisius berjalan dengan baik tanpa ada pengaruh Kepala Sekolah yang merupakan seorang rohaniawan yang sekaligus pemimpin sekolah. Bentuk komunikasi yang terus dikembangkan dan diterapkan di SMP Kanisius adalah refleksi. Makna dari refleksi merupakan bentuk komunikasi seseorang dengan pribadinya sendiri. Hal ini menjadi keunggulan konsep komunikasi yang diterapkan bagi siswa, guru serta kepala sekolah sendiri yang merupakan seorang rohaniawan. (2). Programmed decisions dilaksanakan berdasarkan tanggung jawab serta wewenang yang dimiliki 
kepala sekolah. Pemilihan staf kerja dan mengusulkan ke pihak yayasan Budi Siswa untuk pengesahan atau pengangkatan, mengadakan evaluasi staf untuk kenaikan jenjang kepangkatan/golongan kerja, memanggil dan memberikan teguran baik secara lisan maupun tertulis (surat peringatan) terhadap pegawai edukatif yang melanggar disiplin dan kode etik profesi sebagaimana telah digariskan oleh yayasan Budi Siswa. Nonprogrammed decisions yang merupakan pengambilan keputusan yang diambil untuk mengatasi masalah manajemen yang unik dan komplek. Perubahan jumlah paralel kelas, sistem moving class, pemberian penghargaan untuk siswa guru dan karyawan, kegiatan research paper atau karya tulis ilmiah merupakan program sekolah yang diterapkan oleh Kepala Sekolah SMP Kanisius selama masa jabatannya demi peningkatan mutu sekolah. (3) Academic and Humaniora Award merupakan bentuk dari intrinsic reward yang ditujukan bagi para siswa SMP Kanisius. Proses pemberian penghargaan berawal dari motivasi untuk mengerahkan segala daya untuk menciptakan unjuk kerja individu yang dipengaruhi oleh kemampuan, ketrampilan dan pengalaman. Extrinsic reward dalam bentuk financial rewards, interpersonal rewards dan promotion merupakan bentuk pemberian penghargaan yang diberikan bagi guru dan karyawan SMP Kanisius Jakarta. Bagi para siswa bentuk penghargaan ini memacu siswa untuk terus berprestasi dan meningkatkan rasa kebanggaan menjadi siswa Kanisius. Bagi para guru dan karyawan pemberian penghargaan ini dirasakan sebagai bentuk penghargaan atas kinerjanya, hal ini terus memotivasi untuk selalu bekerja penuh samangat dan tanggung jawab yang besar untuk meningkatkan prestasi kerjanya.

Rekomendasi. (1). Bagi peneliti bidang manajemen pendidikan : Penelitian kualitatif yang berfokus pada kepemimpinan kepala sekolah masih sangat luas untuk dikembangkan. Lingkup kepemimpinan kepala sekolah terus berkembang sesuai perkembangan jaman yang dipengaruhi oleh perkembangan sosial, politik dan budaya masyarakat serta pengaruh kebijakan-kebijakan pemerintah dibidang pendidikan nasional. (2). Bagi Kepala Sekolah SMP Kolese Kanisius Jakarta : SMP Kanisius merupakan salah satu sekolah yang bisa dijadikan sebagai contoh pengelolaan sekolah yang terus mengembangkan dan meningkatkan mutu pendidikan dan pengajaran dengan latar belakang sejarah perkembangannya. Bentuk komunikasi, pengambilan keputusan serta pemberian penghargaan yang diterapkan di SMP Kanisius menunjukan manfaat yang sangat besar dalam perkembangan kemajuan sekolah, evaluasi dan pengawasannya harus terus ditingkatkan. 


\section{DAFTAR RUJUKAN}

Ivancevich, John M., Robert Konopaske dan Michael T. Matteson, Organizational Behavior and Management 10th edition. New York: McGraw-Hill, 2014.

Ivancevich, John M., Robert Konopaske dan Michael T. Matteson, Perilaku dan Manajemen Organisasi edisi ketujuh, terjemahan Dharma Yuwono. Jakarta:Erlangga, 2007.

Newstorm, John W., Organizational Behavior : Human Behavior at Work $13^{\text {th }}$ edition. New York : McGraw-Hill Companies, 2011.

Robbins, Stephen P. dan Timothy A. Judge, Organizational Behavior 15 ${ }^{\text {th }}$ edition. England: Pearson Education Limited, 2013.

Schermerhorn et al., Organizational Behavior $11^{\text {th }}$ edition. USA : John Wiley \& Sons, Inc. 2011.

Stronge, James H., Holly B. Richard dan Nancy Catano, Kualitas kepala Sekolah Yang efektif terjemahan oleh Siti Mahyuni. Jakarta : PT Indeks Permata Puri Media, 2013.

Tim Penulis, Buku Panduan Akademik SMP Kolese Kanisius Jakarta 2012-2013. Jakarta : Kolese Kanisius 2012.

Yin, Robert K., Case Study Research Design and Methods Fourth Edition. Thousand Oaks: Sage Publications, 2009. 